\title{
O KATEGORIACH BIBLIJNYCH W POEMACIE KAROLA WOJTYŁY „PIEŚŃ O BLASKU WODY”
}

\author{
...obecność wasza nie tylko trwa, lecz objawia - \\ Karol Wojtyła, Pieśń o blasku wody ${ }^{1}$
}

Poemat Karola Wojtyły „Pieśń o blasku wody” powstał w 1950 roku i w tym samym roku został opublikowany w numerze 19. „Tygodnika Powszechnego”. Jest to pierwszy z sześciu utworów literackich Karola Wojtyły sygnowanych pseudonimem Andrzej Jawień. ${ }^{2}$ Wśród nich znajdują się jeszcze takie poematy jak: „Matka” również z roku 1950, „Myśl jest przestrzenią dziwną” napisany w 1952 roku, „Kamieniotom” z 1956 roku, „Profile Cyrenejczyka” z roku 1957 oraz utwór „Przed sklepem jubilera. Medytacja o sakramencie matżeństwa przechodzaca chwilami w dramat" napisany w roku 1960. Ponadto pseudonimem Andrzej Jawień zostały opatrzone jeszcze dwa artykuły Karola Wojtyły podejmujące problematykę teorii poezji i dramatu. Pierwszy z nich zatytułowany „Dramat stowa i gestu” został opublikowany w 1957 roku w numerze 14. Tygodnika Powszechnego; drugi natomiast pt. „Rapsody Tysiąclecia" ukazał się w roku 1958 na łamach numeru 3. tego czasopisma.

\footnotetext{
* Dr Dorota HawrYluk - Katolicki Uniwersytet Lubelski Jana Pawła II, e-mail:dorotaih@o2.pl.

${ }^{1}$ K. Wojtyła, Pieśń o blasku wody, w: Karol Wojtyła. Poezje. Dramaty. Szkice. Tryptyk rzymski. Jan Pawet II, M. Skwarnicki, Kraków 2004, s. 96.

2 Na podstawie sporządzonego przez K. Dybciaka „Kalendarium”, aktywność literacka Karola Wojtyły vel Andrzeja Jawienia przedstawia się następująco: poemat pt. „Matka” został opublikowany w grudniu 1950 roku w „Tygodniku Powszechnym” nr 50, poemat „Myśl jest przestrzenia dziwną” ukazał się w roku 1952 w „Tygodniku Powszechnym” nr 42, artykuł o Teatrze Rapsodycznym pt. „Dramat słowa i gestu” opublikowano 7 kwietnia 1957 roku w „Tygodniku Powszechnym”, poemat „Kamieniołom” został opublikowany również w roku 1957 w czasopiśmie „Znak” nr 6. Następnie w 1958 roku 19 stycznia w „Tygodniku Powszechnym” Andrzej Jawień opublikował swoją recenzję ze spektaklu „Króla Ducha”, który pt. „Legendy złote i błękitne” stanowił premierę inaugurującą nowy okres pracy Teatru Rapsodycznego. W roku 1958 opublikował także w „Tygodniku Powszechnym” nr 13 poemat pt. „Profile Cyrenejczyka”. W 1960 roku w czasopiśmie „Znak” nr 12 nastąpiła publikacja utworu „Przed sklepem jubilera. Medytacja o sakramencie małżeństwa przechodząca chwilami w dramat”. - Por. K. Dybciak, Karol Wojtyła a literatura, Tarnów 1991, s. 133-135.
} 
Utwór „Pieśń o blasku wody” otwiera cytat pochodzący z Ewangelii św. Jana: A odpowiadając Jezus rzekt jej: Każdy, kto pije tę wodę, znowu pragnać będzie; kto jednak napije się wody, która Ja mu dam, nigdy nie uczuje pragnienia $(\mathrm{J} 4,13)$. Powyższe słowa - jak i formuła tytułu utworu - zdają się wprost wskazywać, że główną kategorią, wokół której będzie snuła się poetycka medytacja jest pragnienie. W myśli biblijnej, w odróżnieniu chociażby od założeń buddyzmu, gdzie za najwyższą doskonałość uznaje się m.in. „zabicie pragnienia” - kategoria ta przypomina, że u podstaw wszystkich pragnień człowieka znajduje się jego wymaganie istotne: posiadać życie w całej swojej pełni ze wszystkimi jego możliwościami rozwoju. ${ }^{3}$ To dążenie ludzkiej natury jest nie tylko zgodne z odwiecznym porządkiem wpisanym w nią przez Stwórcę, ale i zostaje przedziwnie przez Niego naznaczone życiem i zbawczą misją Jezusa Chrystusa, który przyszedł po to, aby Jego owce miały życie i miały je w obfitości (por. J 10, 10). W swoim tekście Karol Wojtyła omawia powyższą problematykę w kontekście dwóch metafor, zaczerpniętych z wybranego przez siebie fragmentu ewangelicznego. Pierwsza odnosi się do symbolu wody. W języku biblijnym oznacza ona najczęściej Prawo Boże lub samego Boga ${ }^{4}$. Prawdę tę potwierdza m.in. Księga Kapłańska czy Księga Powtórzonego Prawa, gdzie czytamy, że jeżeli Izraelici żyją według Prawa Bożego i słuchają głosu Boga, Bóg otwiera niebiosa, aby zesłać deszcz w swoim czasie (por. Kpł 26, 3-10; Pwt 28, 1-14). Dla wyznawców Chrystusa woda ma charakter wybitnie soteriologiczny i nawiązuje do tajemnicy otrzymanego chrztu. Z zasygnalizowaną symboliką akwatyczną

${ }^{3}$ Por. X. Léon-Dufour, Stownik teologii biblijnej, Poznań 1990, s. 760.

${ }^{4}$ Jako ciekawostka może posłużyć fakt, że w najpopularniejszym wydaniu Pisma świętego w języku polskim zwanym Biblią Tysiąclecia słowo „woda” występuje aż 588 razy. Z jej symboliką mamy do czynienia na początku Księgi Rodzaju w opisie stworzenia, gdzie czytamy o bezmiarze wód i o Duchu Bożym unoszącym się nad wodami (por. Rdz 1,2), który w ten sposób jakby rezerwuje dla nich bardzo szczególne zadania do spełnienia. Woda jest m.in. skutkiem i oznaką Bożego błogosławieństwa wobec tych, którzy są wierni Bogu i Jego Prawu (por. Ps 133, 3). Psalmista powie: Boże [...] Twoja droga wiodła przez wody, Twoja ścieżka przez wody rozległe $i$ nie znać było Twych śladów (Ps 77, 20), nawiązując do zwycięskiego przejścia Izraelitów przez dno Morza Czerwonego, kiedy to dane było im widzieć mur wód po swojej prawej i po lewej stronie (por. Wj 14, 21-22). Do idei powróci się w księgach prorockich, w których woda stanie się symbolem zbawienia mesjańskiego, np. w wizji Ezechiela woda wypływająca ze świątyni symbolizuje moc ożywczą Boga, która rozprzestrzeni się w czasach mesjańskich i pozwoli ludziom przynosić owoc w pełni (por. Ez 47, 12). Natomiast tak charakterystyczny motyw „wody żywej” pojawi się dopiero w tekstach Nowego Testamentu, w Ewangelii św. Jana w rozmowie z Samarytanką. W oparciu o różne przesłanki zawarte w treści całej czwartej Ewangelii, egzegeci upatrują w „,wodzie żywej” symbolu Ducha Świętego oraz nauki i mądrości objawionej przez Chrystusa. Doskonale nawiązuje do tej prawdy św. Ambroży pisząc: „O wodo, która zasłużyłaś sobie stać się sakramentem Chrystusa, która wszystko obmywasz, nie będąc obmyta! Od ciebie zależy początek, od ciebie koniec, a raczej ty sprawiasz, iż końca nie znamy". - Św. Ambroży, Wykład Ewangelii św. Lukasza, Warszawa 1977, s. 422. 
łączy się metafora studni, której motyw z racji swych uwarunkowań historycznych nabierze w poemacie Karola Wojtyły szczególnego znaczenia. Mowa jest o studni położonej w Samarii w pobliżu miejscowości Sychar na polu, które według Rdz 33, 18-19 i Joz 24, 32 nabył Jakub od Sychemity Chamora za sumę stu kesitów (tzn. sztuk srebra, co tłumaczy się również na podstawie Hi 42, 11 jako ,jagniąt”). Tę studnię później patriarcha Jakub podarował swemu synowi Józefowi (por. J 4, 3-6). ${ }^{5}$ $\mathrm{Z}$ powodu podziałów terytorialnych, jakich dokonali między sobą synowie Jakuba, mieszkańcy Judei i Samarii od wieków toczyli rywalizację na tle politycznym i religijnym, oskarżając się nawzajem o herezję. Wynikało to w głównej mierze z faktu, że po zniszczeniu państwa izraelskiego Samarytanie pozostali na swoim terytorium, a będąc potomkami Izraelitów dopuścili się łączenia z kolonistami asyryjskimi. W związku z tym, Judejczycy uważali ich za nieczystych i traktowali pogardliwie. Swoją nienawiść kierowali szczególnie do mieszkańców Sychem od roku 432 przed Chrystusem, kiedy to na znajdującej się nieopodal górze Garizim perski namiestnik Sanballat zbudował swemu zieńciowi Manassesowi świątynię na wzór jerozolimskiej. ${ }^{6}$ Tekst ewangeliczny przypomina o górze Garizim w związku z rozmową, jaka wywiązała się między Samarytanką a Chrystusem:

$<$ Panie, widzę, że jesteś prorokiem. Ojcowie nasi oddawali cześć Bogu na tej górze, a wy mówicie, że w Jerozolimie jest miejsce, gdzie należy czcić Boga $>$. Odpowiedział jej Jezus: $<$ Wierz Mi, kobieto, że nadchodzi godzina, kiedy [...] prawdziwi czciciele będą oddawać cześć Ojcu w Duchu i prawdzie (J 4, 19-23).

Obecnie sąsiadująca z górą Garizim miejscowość Sychar nosi nazwę Nablus. Wzniesiono tam greckokatolicką świątynię, w której podziemiach, według tradycji - znajduje się studnia utożsamiana z Jakubową. Dzisiaj te miejsca należą do Autonomii Palestyńskiej. Należy zaznaczyć, że występująca w Biblii nazwa Sychar nie jest błędną transkrypcją nazwy Sychem (jak dawniej twierdzono), ale nazwą właściwą miasta, które zostało wzniesione na miejscu dawnego Sychem, zniszczonego w roku 128 przed Chrystusem. ${ }^{7}$ Tak więc: najpierw istniało miasteczko o nazwie

${ }^{5}$ Studnia Jakuba położona w sąsiedztwie miasta Tel Balata zlokalizowanego w pobliżu południowo-zachodniej granicy miejscowości Nablus w Autonomii Palestyńskiej. Głębokość studni liczy około 23 - 29 metrów, a średnica około 2, 7 metrów. Nad zbiornikiem wzniesiono sklepienie z wąskimi otworami. Poziom wody zależy od pory roku.

${ }^{6}$ Świątynia na górze Garizim (Dżebel el Tur ok. 870 m n.p.m.) stała się przyczyną całkowitego rozdziału Samarii od Jerozolimy. Na kartach Starego Testamentu wielokrotnie wspomina się o górze Garizim, jako o pierwszym miejscu świętym dla Izraela w Ziemi Obiecanej. Tutaj Izraelici z nakazu Mojżesza odnowili przymierze z Bogiem i błogosławili tych, co zachowują Prawo Boże (por. Joz 30-35). W okolicy tej góry swój pierwszy ołtarz dla Pana zbudował Abraham (por. Rdz 12, 6-7). W tej okolicy został także postawiony namiot Jakuba i tutaj później zakopał on posążki bożków, które zabrała ze swego domu rodzinnego Rachela, ukochana żona Jakuba (por. Rdz 35, 4).

7 Por. X. Léon-Dufour, Stownik Nowego Testamentu, Poznań 1986, s. 585. 
Sychem, potem Sychar, a następnie Nablus. W poemacie „Pieśń o blasku wody” nawiąże się do pierwotnej nazwy Sychem.

Spotkanie Jezusa z Samarytanką, które znalazło się w centrum poetyckiej inspiracji Karola Wojtyły, posiada także swoją bogatą ikonografię. Potwierdzają to liczne istniejące na całym świecie dzieła sztuki sakralnej, powstałe zwłaszcza w dobie włoskiego Renesansu. ${ }^{8}$ I chociaż dominuje w nich różnorodność interpretacyjna, to jednak wszyscy twórcy są zgodni, co do symbolicznego potraktowania nieodzownego w tej scenie atrybutu Samarytanki, którym stał się gliniany dzban. ${ }^{9}$ Jego umiejscawianie na tle studni Jakuba ma przypominać, że rozmowa z Jezusem dotyczyła kwestii pragnienia fizycznego i duchowego. Warto przy tej okazji wspomnieć o pewnym dziele malarskim powstałym w Polsce, które z racji swoich nieprzeciętnych walorów estetycznych i historycznych zasługuje na szczególną uwagę. Jest to Tryptyk Jerozolimski z Bazyliki Mariackiej w Gdańsku. Pierwotnie był on umieszczony w Kaplicy Jerozolimskiej (stąd nazwa) przy południowym ramieniu transeptu świątyni. Od roku 1945 przechowywany jest w zbiorach warszawskiego Muzeum Narodowego. Tryptyk Jerozolimski namalowany został ok. 1497 roku przez nieznanego malarza zaznajomionego z malarstwem dolno-reńskim i niderlandzkim. Dzieło przedstawia wybrane epizody z życia Jezusa Chrystusa ukazane w konwencji narracyjno-symultanicznej. W tle widoczne wyobrażenie panoramy Jerozolimy. Na skrzydłach bocznych, po naszej lewej stronie mamy przedstawione: Ucieczke Świętej Rodziny do Egiptu, Rzeź Niewiniątek, Cud z chlebem oraz Pościg Heroda, po prawej natomiast widoczne są Wjazd Chrystusa do Jerozolimy i Wypędzenie przekupniów ze świątyni. Na rewersach skrzydeł tryptyku znajduje się cykl Pasji Chrystusa od Ostatniej Wieczerzy, po Złożenie Chrystusa do Grobu. Od strony ideowej tryptyk obrazuje słuszność nauki Chrystusa. Wyraźnie nawiązują do tego epizody z części środkowej ołtarza, czyli Nauczający 12 - letni Chrystus w światyni, znajdująca się w centrum Rozmowa Chrystusa z Samarytanka oraz Kuszenie Chrystusa. W tym kontekście przypomina się znana koncepcja malarza Jacksona Pollock'lego, który uważał, że sztuka kryje w sobie tak dynamiczny i operacyjny

${ }^{8}$ Należy zaznaczyć, że wśród różnych interpretacji spotkania przy studni Jakuba wyróżni się dwa zasadnicze rodzaje. Niektórych malarzy interesowała bardziej pierwsza część rozmowy, gdy Jezus siedział przy studni zmęczony i spragniony, a Samarytanka podeszła, aby zaczerpnąć wody. Inni malarze skupiali się na wymianie zdań na końcu spotkania, kiedy to kobieta chyli czoło przed elokwencją Jezusa i objawieniem Jego mesjańskiego posłannictwa, a w tle ukazują się apostołowie niosący żywność. Natomiast, co wydaje się zaskakujące, nie ma w obrazach podejmowania wątku czci Boga „w Duchu i prawdzie". - Por. S. Zufii, Nowy Testament. Postacie i epizody, Warszawa 2007, s. 179-180.

${ }^{9}$ Motywem spotkania Jezusa z Samarytanką przy studni w Sychem zajmowali się m.in. tacy malarze jak: Annibale Carracci, Domenico Fiasella, Giovanni Francesco Barbieri, Jan van Orley, Jacopo Tintoretto, Paolo Veronese, Ferdinand George Waldmuller, Jacek Malczewski i Henryk Siemiradzki. Na uwagę zasługują także: sceny mozaikowe i ikony np. z Monasteru z Góry Athos i Lubljany, czy freski np. z kościoła św. Apolinarego w Ravennie. 
potencjał, że bardziej służy temu, aby coś uczynić WIDOCZNYM, niż aby stać się tego reprezentacją. A zatem, kontakt ze sztuką może istotnie przyczynić się do odkrycia nowych horyzontów interpretacyjnych nie tylko słowa literackiego, ale także Słowa Bożego. Dzieje się tak, ponieważ cechą wyróżniającą tekst biblijny - jak wyraźnie to zaznacza Jan Paweł II w encyklice „Fides et ratio” jest przeświadczenie, że istnieje głęboka i nierozerwalna jedność pomiędzy poznaniem rozumowym a poznaniem wiary. ${ }^{10}$ Nie ma więc powodu do jakiejkolwiek rywalizacji między rozumem i wiarą: rzeczywistości te wzajemnie się przenikają, każda zaś ma swoją własną przestrzeń, w której się realizuje.

Poemat „Pieśń o blasku wody” składa się z ośmiu części. Symbolika liczby osiem wiąże się z tajemnicą powtórnych narodzin do wiecznego życia z Bogiem, a wskazując wprost na Osobę Jezusa Chrystusa nadaje utworowi Karola Wojtyły nie tylko chrystocentryczny, ale i wybitnie chrystoformiczny charakter. ${ }^{11} \mathrm{Już} \mathrm{w}$ pierwszej części utworu noszącej tytuł „Nad studnia w Sychem” Jezus Chrystus jawi się jako Nowy Prawodawca, który nie tylko ośmieli się przekroczyć nabudowany przez lata mur niechęci między Żydami i Samarytanami, ale także podejmie rozmowę z kobietą samarytańską, co znacznie odbiegnie od panującego kanonu zachowania. Zgodnie z tradycją żydowscy nauczyciele przebywający na ulicy lub w podróży, unikali rozmów z kobietami nawet wówczas, kiedy były to ich żony. Święty Jan Ewangelista fakt rozmowy przy studni z Samarytanką opisze bardzo precyzyjnie:

\begin{abstract}
Było to około szóstej godziny. Nadeszła [tam] kobieta z Samarii, aby zaczerpnąć wody. Jezus rzekł do niej: <Daj Mi pić!>. Jego uczniowie bowiem udali się przedtem do miasta dla zakupienia żywności. Na to rzekła do Niego Samarytanka: $<$ Jakżesz Ty będąc Żydem prosisz mnie Samarytankę, bym Ci dała się napić?>. Żydzi bowiem z Samarytanami unikają się nawzajem. Jezus odpowiedział jej na to: $<$ O, gdybyś znała dar Boży i [wiedziała] kim jest Ten, kto ci mówi: „Daj Mi się napić” - prosiłabyś Go wówczas, a dałby ci wody żywej> (J 4, 6-10).
\end{abstract}

10 Por. Jan Paweł II, Fides et ratio, Poznań 1998, s. 29-30.

11 Już w czasach starożytnych ósemka uchodziła za symbol tego, co doskonałe. Według Platona zawędrować do ósmego dnia oznaczało osiągnąć niebo. Od początku także Kościół był zgodny w interpretacji symboliki liczby osiem, widząc w niej ,pierwszy dzień tygodnia” następujący po siedmiu dniach - dzień, w którym Zmartwychwstał Chrystus. Święty Justyn powie, że wielka jest tajemnica tego ósmego dnia, który nie przestaje być równocześnie pierwszym, symbolem nowego stworzenia, wiecznego wieku, istniejącego poza światem ziemskim podlegającym śmierci i przemijalności. Tajemnica liczby osiem wypełni się jednak dopiero w dniu Sądu Ostatecznego, kiedy każdemu zostanie oddane według jego uczynków - i jak zaznacza Klemens Aleksandryjski - ci, którzy trudzili się o dobre dzieło przez siedem dni świata, zostaną pocieszeni dnia ósmego, niczym niezmąconym oglądaniem Boga i jako sprawiedliwi odpoczną na świętej Górze Boga. W związku z tym, czy można się dziwić, że drodze osiągania ewangelicznej doskonałości towarzyszy także reguła obejmująca błogosławieństwa w liczbie osiem, których zamysł ukazał Jezus w swoim Kazaniu na Górze? (por. Mt, 5, 1-12) - Por. D. Forstner, Świat symboliki chrześcijańskiej, Warszawa 1990, s. 4850; por. M. Michalski, Antologia literatury patrystycznej, Warszawa 1975, s. 97; por. Campenhausen H., Ojcowie Kościoła, Warszawa 1967, s. 13-22. 
Z dalszego fragmentu wynika, że kobieta słysząc o „wodzie żywej” będzie miała na myśli tak upragnioną na Wschodzie wodę źródlaną (por. J 4, 11-13). Jezus jednak wyjaśnia, że chodzi Mu o taką wodę, którą może dać jedynie tylko On, i która ma moc ugasić ludzkie pragnienie na zawsze (por. J 4, 13-14).

Na tej podstawie, bardzo interesujące wydaje się być poetyckie dopowiedzenie Karola Wojtyły. Jego autorska medytacja odwoła się zaskakująco w tym kontekście do percepcji wzrokowej, istotnie poszerzając zakres znaczeniowy kategorii pragnienia. I tak, na początku pierwszej części utworu Jezus zaprosi Samarytankę do spojrzenia najpierw w głąb Jakubowej studni:

Popatrz - tam łuską srebrzystą nieustannie się woda odrywa, oto głębi brzemieniem drży

jak źrenica czując dno obrazu. ${ }^{12}$

Uchwycony w narracji widok tafli wody, porównany zostaje do źrenicy oka. O ile oko w interpretacji biblijnej stanowi symbol ludzkich aktów duchowych i jest obrazem wewnętrznego poznania, to źrenica oka, której w terminologii greckiej odpowiada określenie kore oznacza córkę oka. ${ }^{13} \mathrm{~W}$ znaczeniu biblijnym termin źrenica zarezerwowany jest zatem dla tych, którzy są szczególnie drodzy Bogu, i których pragnie On, jak Ojciec otaczać swoją wyłączną troską ${ }^{14} \mathrm{~W}$ Księdze Powtórzonego Prawa czytamy, że

dziedzictwem Jego wydzielonym jest Jakub. Na pustej ziemi go znalazł, na pustkowiu, wśród dzikiego wycia, opiekował się nim i pouczał, strzegł jak źrenicy oka (Pwt 32, 9-10).

Tak więc, uważne patrzenie Samarytanki w głąb studni ma na celu wprowadzenie jej w przestrzeń własnej głębi, aby mogła odkryć tajemnicę Bożych przeznaczeń i niejako narodzić się na nowo w tajemnicy swojej tożsamości. W zamyśle autorskim Karola Wojtyły dokona się to w swoistym misterium obmycia oczu w blasku wody, co może wskazywać na konieczność przyjęcia oświecenia z zewnątrz. $\mathrm{Z}$ tekstu zdaje się jednak wynikać, że kobieta na początku będzie odnosić się do tego sceptycznie, na co Chrystus odpowie:

Woda jednak miejsca zmęczone wokół twych oczu przemywa, gdy odbiciem szerokich liści dosięga twojej twarzy.

Tak daleko do źródła. ${ }^{15}$

Warto przy tej okazji zatrzymać się przy owych „miejscach zmęczonych wokół oczu" Samarytanki, tych oczu, w których tak dogłębnie czytał Jezus:

${ }^{12}$ K. Wojtyła, Pieśń o blasku wody, w: Karol Wojtyła. Poezje. Dramaty. Szkice. Tryptyk rzymski. Jan Pawet II, dz. cyt., s. 95.

${ }_{13}$ Por. X. Léon-Dufour, Stownik Nowego Testamentu, dz. cyt., s. 452.

${ }_{14}$ Por. D. Forstner, Świat symboliki chrześcijańskiej, dz. cyt., s. 347-348.

${ }^{15}$ K. Wojtyła, Pieśń o blasku wody, w: Karol Wojtyła. Poezje. Dramaty. Szkice. Tryptyk rzymski. Jan Pawet II, dz. cyt., s. 95. 
Te oczy znużone to znak, że ciemne wody nocy płynęły w słowach modlitwy (-nieurodzaj, nieurodzaj dusz-) $^{16}$

W duchowości katolickiej mówi się o znużeniu w kontekście walk przeżywanych przez człowieka w czasie modlitwy. ${ }^{17}$ Znużenie najczęściej objawia istniejący i zakamuflowany w człowieku brak wiary, a poddanie się pokusie znużenia prowadzi ostatecznie do porzucenia wymagań życia na poziomie wartości duchowych. W takiej sytuacji człowiek egzystencjalnie zamyka się wówczas tylko na płaszczyźnie wegetatywno-zmysłowej i zaczyna kroczyć drogą ciągłego sycenia zmysłów. Prowadzi to z czasem do całkowitego duchowego zaślepienia i owocuje pełnym umęczenia błądzeniem oraz rozpaczliwym przekonaniem o własnym niespełnieniu.

Powyższą problematykę rozwija druga część utworu nosząca tytuł: „Gdy otworzysz oczy w głębi fali...”. Autor podejmie w niej dalszą refleksję na temat symboliki oczu i odzwierciedlającego się w nich duchowego nastawienia. ${ }^{18} \mathrm{~W}$ związku z tym interesujący wydaje się następujący fragment poematu:

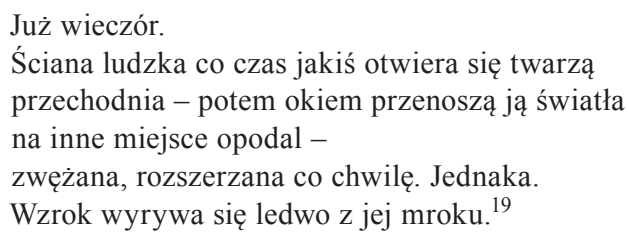

Pytanie, które rodzi się już na początku dotyczy zastosowanej w tekście metafory ściana ludzka. Klucz interpretacyjny może stanowić tutaj wypracowana na płaszczyźnie psychologii terminologia. W jej ramach mówi się o ścianie w sytuacji konfliktogennego dla człowieka doświadczenia muru psychologicznego związanego z doznaniem jakiejś granicy, bariery nie do pokonania czy braku życiowych perspektyw. ${ }^{20}$ Jest to sytuacja, która niejednokrotnie łączy się z zamknięciem na nowe możliwości lub przeżywaniem przez człowieka schyłku dotychczasowej drogi życia, co porównuje się często z jej wieczorem. Jeśli zestawimy ten opis z użytym

16 Tamże.

17 Por. Katechizm Kościoła Katolickiego, Poznań 1994, s. 612-614.

18 Warto zaznaczyć, że w teologii biblijnej otworzyć oczy oznacza uwolnić kogoś od ciemności duchowych i przywrócić mu dar rozpoznawania. Psalmista powie: Moje oczy się budza przed nocnymi strażami, aby rozważać Twa mowę (Ps 119, 148). Ważne jest zatem, aby oko ludzkie - jak zaznacza to sam Zbawiciel w Kazaniu na Górze - było rzeczywiście światłem ciała: Jeśli więc twoje oko jest zdrowe, całe ciało będzie $w$ świetle (Mt 6, 22).

19 K. Wojtyła, Pieśń o blasku wody, w: Karol Wojtyła. Poezje. Dramaty. Szkice. Tryptyk rzymski. Jan Pawet II, dz. cyt., s. 96.

20 Problematykę szeroko omawia m.in. B. Pilecka, Kryzys psychologiczny. Wybrane zagadnienia, Kraków 2004; K. Budzyń, D. Kubacka-Jarecka, Kryzys. Interwencja i pomoc psychologiczna, Toruń 2003; K. Balawajder, Konflikty interpersonalne: analiza psychologiczna, Katowice 1992. 
przez Karola Wojtyłę określeniem ludzka, to może tutaj chodzić o doznawanie przez człowieka problemów, których źródłem jest nieprzychylne lub wrogie mu środowisko. Autor wprowadza nas zatem w głębszy kontekst spotkania Chrystusa z Samarytanką i rozmowy, która wówczas miała miejsce. Z fragmentu wynika, że Jezus jawi się kobiecie, jako Ten, który nie tylko dostrzega jej problem, ale także doskonale zna rzeczywiste jego przyczyny. Świadczą o tym chociażby następujące słowa:

A ja ci powiadam, że to tylko twój wzrok

dostrzega ludzi tak słabo [...].

Właściwie odsłania ich to, co najbardziej ukryte w nich

i czego żaden nie wypala płomień. ${ }^{21}$

Jest to wyraźna zachęta Zbawiciela, aby Samarytanka w swoim odbiorze rzeczywistości zechciała zejść na poziom serca i pozwoliła przeniknąć się właśnie tam Bożej światłości:

A kiedy przymkniesz oczy, przestrzeń znowu się staje pełniejsza
wprost niepojętych treści - oto ludzi rozsuwa się mrok [...].
Byle oczy otworzyć inaczej,
otworzyć inaczej niż zwykle.
I nie zapomnieć widzenia, którym wówczas się wzrok napawał. ${ }^{22}$

Kobieta ma zrozumieć, że największym nieszczęściem człowieka jest z jednej strony: poddanie się pokusie znużenia życiem, postrzeganym jako bezsensowne i wewnętrznie sprzeczne, $z$ drugiej zaś: pielęgnowanie w sobie nieumiejętności kochania, które prowadzi ostatecznie do chciwego zawłaszczania przestrzeni innych osób. Dlatego Chrystus od początku tak zdecydowanie proponuje jej zmianę sposobu patrzenia na rzeczywistość. Niezwykle trafnie ujmie to Krzysztof Dybciak pisząc: „Oczy prześwietlone światłem dochodzącym z zewnątrz, zamienione, oświetlające swym jasnym rdzeniem i przeobrażające rzeczywistość, zdolne są już zobaczyć rzeczy niezwykłe i pomagać innym władzom duszy". ${ }^{23}$ Tak więc, dla Samarytanki poszukującej zaspokojenia swoich najgłębszych pragnień przychodzi wsparcie, które raz na zawsze położy kres niewłaściwej i przysparzającej jej wielu cierpień drodze myślenia.

Trzecia część utworu nosząca tytuł: „Słowa niewiasty u studni, które wypowiedziała odchodząc" to niezwykle czytelny rezonans ducha Samarytanki. Jak wynika z wizji poetyckiej Karola Wojtyły korespondującej ściśle z przekazem ewangelicznym, Chrystus w czasie rozmowy z kobietą z Samarii dotknął problemu jej życiowego uwikłania. Na podstawie tekstu św. Jana wiadomo, że dokonało się
21 Tamże.
22 Tamże.
${ }^{23}$ K. Dybciak, Karol Wojtyła a literatura, dz. cyt., s. 42. 
to poprzez skierowaną do kobiety prośbę: Idź, zawołaj swego męża i wróć tutaj! (J 4, 16). Relacja ewangelisty zdaje się wskazywać w sposób oczywisty na cel tego zbawczego zabiegu Jezusa: kobieta ma w wolności sama wypowiedzieć to, co tak naprawdę jest powodem udręki jej serca. Jego polecenie wewnętrznie nie blokuje Samarytanki, ale otwiera w niej przestrzeń prawdy tak konieczną, aby mogło dojść do przemiany całego jej życia. ${ }^{24} \mathrm{~W}$ ewangelii czytamy:

A kobieta odrzekła Mu na to: $<$ Nie mam męża $>$. Rzekł do niej Jezus: $<$ Dobrze powiedziałaś: Nie mam męża. Miałaś bowiem pięciu mężów, a ten, którego masz teraz, nie jest twoim mężem. To powiedziałaś zgodnie z prawdą>. (J 4, 17-18)

Jak pamiętamy z wcześniejszego opisu, Samarytanka przyszła do studni zaczerpnąć wody około szóstej godziny (J 4, 6), czyli w porze naszego południa. Co ciekawe, w Samarii z racji panujących upałów nie wychodziło się po wodę w południe i tę czynność rezerwowano na porę wieczorową. Wtedy też ludzie spotykali się ze sobą, rozmawiali i dzielili wieściami. Z jakichś powodów kobieta chciała tego uniknąć. Być może związek z mężczyzną, o którym nic nie wiemy, narażał ją na publiczną dezaprobatę. Cała sytuacja jednak była znana Chrystusowi i co więcej - On jakby wychodzi temu wszystkiemu na przeciw. Rozmowa, którą od początku inicjuje Zbawiciel staje się dla kobiety spotkaniem z Jego pełnym miłości Sercem, w którym, zgodnie z ewangelicznym przesłaniem, mogą znaleźć ukojenie wszyscy, którzy są utrudzeni i obciążeni. ${ }^{25}$ Nie ma więc podstaw, aby sądzić, że Samarytanka w czasie tego spotkania mogła czuć się w jakiś sposób oskarżona i upokorzona. ${ }^{26}$ Odpowiedź, jakiej udzieliła Jezusowi została przez Niego doceniona i uznana za prawdziwą, co mogło być dla niej jakimś szczególnym wyrazem afirmacji i wsparcia, których tak bardzo pragnęła doświadczyć. ${ }^{27}$ Kolejne frag-

${ }^{24}$ Podobny wydźwięk interpretacyjny proponuje w swoim komentarzu J. Machniak. Czytamy tam m.in., że Samarytanka mimo bólu poznania swej słabości nie czuła się upokorzona: „Niewiasta rozumie, że cierpienie związane z poznaniem prawdy o sobie było dla niej możliwe do zniesienia dzięki miłości”. - J. Machniak, Bóg i człowiek w poezjach i dramatach Karola Wojtyły-Jana Pawła II, Kraków 2007, s. 46.

${ }^{25}$ W ewangelii św. Mateusza znajduje się następująca wypowiedź Jezusa: „Przyjdźcie do Mnie wszyscy, którzy utrudzeni i obciążeni jesteście, a Ja was pokrzepię. Weźcie moje jarzmo na siebie i uczcie się ode Mnie, bo jestem cichy i pokorny sercem, a znajdziecie ukojenie dla dusz waszych. Albowiem jarzmo moje jest słodkie, a moje brzemię lekkie" (Mt 11, 28-30).

${ }^{26}$ W swoim komentarzu do tego ewangelicznego wątku o. Maria Eugeniusz od Dzieciątka Jezus podkreśla, że podczas rozmowy przy studni Jakuba Samarytanka została przez Jezusa jakby uderzona upokarzającym ją odkryciem. Zdaniem tego autora, dopiero to Jezusowe uderzenie doprowadziło do zmiany jej postawy: „Była dotąd wyniosła i niemal obelżywa; a oto staje się pełna szacunku, pokorna i uległa. Poprzez ranę otrzymanego upokorzenia w jej duszę nareszcie może wstąpić światło". - Por. Eugeniusz M. od Dzieciątka Jezus, Chcę widzieć Boga, Kraków 1998, s. 420-421.

${ }^{27}$ Zdecydowanie afirmatywny charakter spotkania Jezusa z Samarytanką podkreślają w swojej publikacji A. A. Terruwe i C. W. Baars, którzy zauważają, że tylko dzięki stałej afirmacji i cierpliwej obecności osoba cierpiąca na brak afirmacji może wzrastać i umacniać się, przechodząc różne etapy rozwoju. Zdaniem autorów, Chrystus zamiast odrzucić Samarytankę przy studni - co jako 
menty poetyckiej medytacji Karola Wojtyły wyraźnie nawiązują do tych przeżyć Samarytanki i są świadectwem przyjętej przez nią łaski:

Od tej chwili moja niewiedza zamknęła się za mną jak drzwi, którymi wszedłeś - poznając to wszystko, czego ja nie wiem I milcząc tylu ludzi przeprowadziłeś przeze mnie.

I dróg dalekich - i ulic rosnące w ludziach zarzewie. ${ }^{28}$

Naznaczony kierunek autorskiej refleksji Karola Wojtyły prowadzi nas zatem ku rozumieniu, na czym polega w swej istocie nawrócenie człowieka. Po pierwsze, inicjatorem tego duchowego procesu jest sam Jezus Chrystus. Po drugie, przykład kobiety samarytańskiej wyraźnie wskazuje, że dzieło to polega na czymś więcej niż na przyjęciu i zastosowaniu znanej formuły. Nawrócić się to wejść razem z Chrystusem w nurt Jego zbawczej łaski, która nieustannie ożywia, tak istotną dla wewnętrznego wzrostu - przestrzeń duchowego dynamizmu człowieka. ${ }^{29} \mathrm{Jak}$ zaznaczy to w swojej późniejszej encyklice „Redemptor hominis” Jan Paweł II, każdy człowiek może odnaleźć tutaj swoją właściwą godność i potwierdzić wartość swego człowieczeństwa, gdyż w Tajemnicy dokonanego przez Chrystusa Odkupienia wszyscy ludzie zostali przez Boga na nowo potwierdzeni i niejako na nowo przez Niego wypowiedziani. Dlatego zdaniem papieża:

Człowiek, który chce zrozumieć siebie do końca - nie wedle jakichś tylko doraźnych, częściowych czasem powierzchownych, a nawet pozornych kryteriów i miar swojej własnej istoty - musi ze swoim niepokojem, niepewnością, a także słabością i grzesznością, ze swoim życiem i śmiercią, przybliżyć się do Chrystusa. Musi niejako w Niego wejść z sobą samym, musi sobie <przyswoić>, zasymilować całą rzeczywistość Wcielenia i Odkupienia, aby siebie odnaleźć. Jeśli dokona się w człowieku ów dogłębny proces, wówczas owocuje on nie tylko uwielbieniem Boga, ale głębokim zdumieniem nad sobą samym. ${ }^{30}$

\footnotetext{
Żyd mógłby uczynić, ponieważ pochodził z innego kraju -zaakceptował ją, mówiąc „Daj mi pić!” (J 4,7). Pierwszym krokiem na drodze do afirmowania innych jest zatem zaprzestanie działań przeciwnych afirmacji. Chodzi tu o krytykowanie, dokuczanie, ciągłe doszukiwanie się błędów, deprecjonowanie, wytykanie i przypominanie dawnych i obecnych braków. Takie działania wg autorów godzą bezpośrednio w godność drugiego człowieka. A oto przykłady delikatnego odrzucenia, kryjące się pod płaszczykiem uprzejmości i wsparcia: mówienie smutnym i zapłakanym dzieciom, by były dzielne, przestały się mazać i pomyślały o tych wszystkich dzieciach, które maja gorzej; szybkie udzielanie porad bez wczucia się w sytuację osoby potrzebującej pomocy. - Por. A. A. Terruwe, C. W. Baars, Integracja emocjonalna - jak uwierzyć, że jesteś kochany i potrafisz kochać, Poznań 2004, s. 212-213.

${ }^{28}$ K. Wojtyła, Pieśń o blasku wody, w: Karol Wojtyła. Poezje. Dramaty. Szkice. Tryptyk rzymski. Jan Pawet II, dz. cyt., s. 96-97.

${ }_{29}$ Por. A. Ballestrero, Wstuchani w Boga, w: Droga do nowego życia, dz. zb. pod red. S. Ruszczyckiego, Kraków 1982, s. 73-74.

30 Jan Paweł II, Redemptor hominis, Wrocław 1994, s.27.
} 
Idea afirmatywnego charakteru spotkania Chrystusa z cierpiącym człowiekiem, którą zawarł w swoim poemacie Karol Wojtyła wpisuje się niewątpliwie w nakreśloną linię jego późniejszego papieskiego nauczania.

Czwarta część utworu pt. „Późniejsze rozpamiętywanie spotkania” jest oryginalną poetycką apologią Osoby Jezusa. Dotknięta uzdrawiającym rozpoznaniem Samarytanka podejmuje opowieść o tym, czego doświadczyła przy studni. Jej myśli koncentrują się wokół nadprzyrodzonego charakteru całego spotkania. Kobieta zaczyna rozumieć, że rozmawiała nie tylko z Prorokiem, ale i zapowiadanym Mesjaszem, tak oczekiwanym zarówno przez Żydów, jak i przez Samarytan:

On poznawał inaczej. Prawie oczu nie podniósł. Był wielkim zbiorowiskiem poznania

- jak studnia blaskiem wody wiejąca przez twarz.

Miał zwierciadło... jak studnia... święcące głęboko.

Nie potrzebował wychodzić z siebie, ani oczu podnosić by odgadnąć.

Widział mnie w sobie. Posiadał mnie w sobie.

Przenikał we mnie bez trudu

i wstydem wytryskał we mnie i myślą stłumioną od dawna.

Jakby dotykał rytmu w moich skroniach

i znużenie ogromne dźwigał we mnie nagle...

i pieczołowicie [...].

Był cały w moim grzechu i w mej tajemnicy.

Powiedz to musiało boleć - to musiało ciążyć

(fala myśli opada tak ciężko jak wieko metalu) -

Milczysz - lecz dzisiaj już wiem, otwarta na zawsze Twym słowem - że wtedy nie

docierpiałam w Tobie właściwych rozmiarów.

[...] dziś każdy ból, który powraca od Ciebie,

po drodze odmienia się w miłość.

Jakiż skrót! Jakaż dobroć poznania!

A przecież nawet nie podniosłeś oczu -

mówiłeś ze mną tylko tamtymi oczami,

które studni głęboki blask odtworzył. ${ }^{31}$

Medytacja poetycka Karola Wojtyły wiedzie nas zatem poza sferę intelektu ku poznawaniu, jakie dokonuje się na poziomie mistycznym. Jest to poznanie, które prowadzi do uczestnictwa w wewnętrznym życiu samego Boga. ${ }^{32}$ Czy biblijne znaczenie słowa poznać wprost nie nawiązuje do tej tajemnicy? W myśli biblijnej poznać oznacza zjednoczenie dwóch bytów w miłości, a zjednoczenie z Bogiem może nastąpić tylko dzięki Chrystusowi i przez Chrystusa. Samarytanka zdaje się jednak zauważać, że wtedy jakby jeszcze nie dojrzała do uczestniczenia w tak wzniosłej tajemnicy. ${ }^{33}$ Spotkanie ze Zbawicielem rzeczywiście skonfrontowało ko-

${ }^{31}$ K. Wojtyła, Pieśń o blasku wody, w: Karol Wojtyła. Poezje. Dramaty. Szkice. Tryptyk rzymski. Jan Pawet II, dz. cyt., s. 97.

32 Por. S. Moysa, Teraz zaś trwaja te trzy, Warszawa 1986, s. 177-178.

${ }^{33}$ Zdaniem M. Zawady uznanie faktu swego stworzenia ma ogromną doniosłość religijną: „Konsekwentnie mówi nie tylko o realnych granicach i ograniczeniach, ale i źródłowej zależności 
bietę z miłością Boga, ale była to również konfrontacja ze stłumionym głęboko jej własnym wstydem, który mógł wynikać z prawdy o przedmiotowym potraktowaniu swego ciała i innego człowieka. ${ }^{34} \mathrm{~W}$ ujęciu Karola Wojtyły Samarytanka bowiem została duchowo wprowadzona w przestrzeń swojej osobistej nietykalności, a więc takiej głębi swego jestestwa, do którego prawo ma tylko Stwórca.

Piąta część utworu zatytułowana „Rozmowy, które prowadził w niej On i ludzie ze ściany wieczoru" zdaje się już nawiązywać do wydarzenia, jakie miało miejsce po rozmowie Jezusa z Samarytanką. Z przekazu ewangelicznego wynika, że kobieta doświadczywszy wewnętrznego podźwignięcia, pozostawiła swój dzban przy studni i pobiegła do miasta, aby o tym opowiedzieć innym ludziom:

$<$ Pójdźcie, zobaczcie człowieka, który mi powiedział wszystko, co uczyniłam: Czyż On nie jest Mesjaszem?>. Wyszli z miasta i szli do Niego [...]. Kiedy więc Samarytanie przybyli do Niego, prosili Go, aby u nich pozostał. Pozostał tam zatem dwa dni. I o wiele więcej ich uwierzyło na Jego słowo, a do kobiety mówili: <Wierzymy już nie dzięki twemu opowiadaniu, na własne bowiem uszy usłyszeliśmy i jesteśmy przekonani, że On prawdziwie jest Zbawicielem świata>. Po dwóch dniach wyszedł stamtąd do Galilei (J 4,29-30. 39-43).

Warto w tym kontekście zwrócić uwagę na słowa samej kobiety, która mówiąc o spotkaniu z Mesjaszem nawiązuje głównie do kategorii widzenia: pójdźcie, zobaczcie. Poetycka refleksja Karola Wojtyły, która tak mocno w tym utworze podkreśla znaczenie daru widzenia prezentuje zatem z jednej strony głęboką spójnię z logiką przesłania biblijnego, z drugiej zaś, jak się za chwilę okaże, autorsko przekroczy jej ramy. Chodzi o zastosowanie specyficznego zabiegu literackiego: przeniesienia

od Stwórcy w darze życia, jak i śmierci [...]. Zakorzenienie w głębi ziemi oraz doskonała znajomość wnętrza przez Boga stanowi część istotnej samoświadomości stworzeń, zależności oczywistej i niekwestionowanej. Pokora uznaje w całej rozciągłości nieskończoną różnicę, dystans istnienia, pomiędzy Powołującym wszystko do istnienia a powołanym do niego". - M. Zawada, Podstawy architektury duchowej. Pokora, Kraków 2006, s. 71-73.

${ }^{34}$ Należy pokreślić, że problematyka zagadnienia wstydu znalazła swoje szczególne miejsce w naukowym opracowaniu Karola Wojtyły w dziele „Miłość i odpowiedzialność”. W rozdziale poświęconym „Metafizyce wstydu” czytamy, że istnieje głęboki związek pomiędzy zjawiskiem wstydu a naturą osoby: „Osoba jest panią samej siebie (sui iuris); nikt inny oprócz Boga-Stwórcy nie ma i nie może mieć w stosunku do niej żadnego prawa własności. Jest własnością siebie samej, ma władzę samostanowienia, nikt nie może naruszać jej samoistności. Nikt nie może uczynić jej swoją własnością, chyba, że ona sama na to pozwoli oddając mu siebie z miłości. Otóż ta obiektywna niedostępność (alteri incommunicabilitas) oraz nietykalność osoby dochodzi do głosu właśnie w przeżyciu wstydu seksualnego. Przeżycie wstydu jest naturalnym oddźwiękiem tego, czym osoba po prostu jest. I tak z jednej strony przeżycie wstydu potrzebuje życia wewnętrznego osoby jako terenu, na którym jedynie może wystąpić, tak sięgając jeszcze głębiej widzimy, że przeżycie to potrzebuje samego bytu osoby jako naturalnej swej podstawy. Wstydzić się może tylko osoba, bo tylko ona z samej swojej natury nie może być przedmiotem używania [...]. Wartość osoby jest ściśle związana z jej nietykalnością, z jej pozycją ,ponad przedmiotem używania”. - K. Wojtyła, Miłość i odpowiedzialność, Lublin 1982, s. 159-161. 
rozmów Zbawiciela z mieszkańcami Sychem na głębiny wnętrza Samarytanki. ${ }^{35}$ Dlatego w strukturze tej części utworu wszystko dokonuje się niejako w jej osobie i poprzez jej osobę. Ten ciekawy introwertyczny chwyt kompozycyjny może mieć na celu z jednej strony: zwrócenie uwagi na istotę samej kontemplacji, która - jak podaje definicja katechizmowa - jest spojrzeniem wiary utkwionym w Jezusa Chrystusa ${ }^{36}$; z drugiej zaś może podkreślać, że osobiste przeżycia Samarytanki są w tym utworze głównym punktem odniesienia. Dokonujący się we wnętrzu kobiety dialog Jezusa z ludźmi ze ściany wieczoru, jeszcze mocniej bowiem akcentuje nadany w utworze jej status i podkreśla specyficzną misję, jaka stała się jej udziałem wobec mieszkańców Sychem. Już na początku bowiem przekonamy się, że słuchający Chrystusa ludzie poczują się przez Niego - tak, jak ona - wewnętrznie podźwignięci i z Nim duchowo złączeni. Słowa, które zostaną skierowane do Jezusa wyraźnie potwierdzą dokonanie się głębokiej przemiany:

- Nie myśl, że chodzisz sam. Towarzyszy Ci ciągle takich jak ja - odmienionych twoim zamyśleniem w nas ... tak, twoim zamyśleniem w nas, jakby słowa prostym przeszczepieniem [...] takich, jak ja, dźwigniętych w mroku tratowanych gwiazd. ${ }^{37}$

W zacytowanym fragmencie może uderzać odwołanie się do samotności Jezusa i skierowanie uwagi na trwały ślad, jaki pozostawia w duszy ludzkiej Jego Słowo. Podobny wydźwięk posiada następny fragment, będący już odpowiedzią Zbawiciela:

- Nie chodzicie samotni.

Nigdy ani na chwilę nie odłącza się od was mój profil,

który w was staje się prawdą, ciągle staje się prawdą

${ }^{35} \mathrm{~W}$ komentarzu do niniejszego fragmentu poematu przedstawionym w artykule pt. Biblijne aspekty spotkania Chrystusa z człowiekiem w twórczości Karola Wojtyły stwierdzono, że „ten dialog nie stanowi aluzji do konkretnej rozmowy prowadzonej przez Jezusa a zapisanej w Piśmie Świętym”. - Por. R. Bogacz, K. Ligas, Biblijny aspekt spotkania Chrystusa z czlowiekiem w twórczości Karola Wojtyły, w: Inspiracje biblijne, dz. zb. po red. T. Jelonki, Kraków 2007, s. 19. W związku z tym należy podkreślić, że analiza tekstu ewangelicznego dotyczącego całego spotkania Jezusa z Samarytanką pozwala na wysnucie jednak innego wniosku i usytuować autorką refleksję Karola Wojtyły na gruncie późniejszego spotkania Chrystusa z mieszkańcami Sychem, do którego doszło rzeczywiście dzięki inicjatywie Samarytanki. Do zajęcia takiego stanowiska upoważnia wnikliwa lektura ukazanego fragmentu na przestrzeni J 4, 5-43 oraz przyjęty kierunek interpretacyjny poematu Karola Wojtyły.

${ }^{36}$ Dochodzi wówczas do przedziwnej wymiany: światło spojrzenia Jezusa oświeca oczy ludzkiego serca i uczy je widzieć wszystko w świetle Jego prawdy oraz Jego współczucia dla wszystkich ludzi. Dzieje się tak, ponieważ kontemplacja kieruje wzrok wprost na misteria życia Chrystusa i w ten sposób uzdalnia do wewnętrznego poznania Pana. - Por. Katechizm Kościoła Katolickiego, dz. cyt., s. 610.

${ }^{37}$ K. Wojtyła, Pieśń o blasku wody, w: Karol Wojtyła. Poezje. Dramaty. Szkice. Tryptyk rzymski. Jan Pawet II, dz. cyt., s. 98. 
i waszej żywej fali rozdarciem niezmiernie głębokim.

Moja twarz spieczona waszych dusz pustynią

ciągle zwiewana oddechem zmęczonego snu -

Dlaczego ze mnie swojego nie wyjmujecie krzyża,

jak ja wyjąłem z was? -

gdy płonął w waszych ramionach i zwisał w ciężkim tchu. ${ }^{38}$

Podjęta w obydwu wypowiedziach problematyka samotności wydaje się być tutaj kluczowa i może jawić się jako rodzaj duchowej przejrzystości przygotowującej człowieka do bytowania na o wiele głębszym poziomie. ${ }^{39}$ Chodzi tutaj o tajemnicę naśladowania kenozy Syna Bożego i upodobnienia się do Niego w miłości aż po Krzyż. Jak dobitnie podkreśla to w swojej późniejszej encyklice „Dives in Misericordia” Jan Paweł II: „Krzyż Chrystusa na Kalwarii wyrasta na drodze tego admirabile commercium, tego przedziwnego udzielania się Boga człowiekowi, w którym równocześnie zawiera się skierowanie do tegoż człowieka wezwanie, aby - oddając Bogu siebie, a w sobie cały widzialny świat - uczestniczył w Bożym życiu, aby stawał się jako Jego syn przybrany uczestnikiem tej prawdy i miłości, która jest w Bogu i która jest z Boga". ${ }^{40}$ Droga tak dogłębnego duchowego zaangażowania może dla osób pozostających w nurcie osobistych zniewoleń okazać się nie do przyjęcia, o czym zdają się mówić ludzie ze ściany wieczoru w kolejnych wersach poematu:

Oni:

kiedy w smutnej ścianie wieczoru odnajdujesz nasze twarze

oślizgłe jak kadłub ryby od światła tylu lamp -

mamy krew, mamy krew

i krwią chcemy uderzyć $!^{41}$

A tymczasem w poetyckim dopowiedzeniu Karola Wojtyły: riposta Jezusa na taki zarzut jest jakby natychmiastowa i demaskująca głęboko ukryty w ludzkim myśleniu błąd:

Przyszedłem przeważyć krwią.

Przyszedłem szukać znużenia - podobny wam. ${ }^{42}$

To na tej podstawie Chrystus chce budować więź z każdym człowiekiem. On jest Bogiem z nami (por. Iz 7, 14) i przychodzi, aby podźwignąć wszystkich pogrążonych w smutku mocą Swojej zwycięskiej Krwi przelanej na Krzyżu. Wymowny

38 Tamże.

${ }^{39}$ Por. M. Zawada, Zaślubiny z samotnościa, Kraków 1999, s. 115.

40 Jan Paweł II, Dives in Misericordia, Lublin 1983, s. 24.

${ }^{41}$ K. Wojtyła, Pieśń o blasku wody, w: Karol Wojtyła. Poezje. Dramaty. Szkice. Tryptyk rzymski. Jan Pawet II, dz. cyt., s. 98.

42 Tamże, s. 99. 
komentarz na ten temat proponuje dalsza część cytowanego powyżej papieskiego dokumentu: „Uwierzyć w Syna ukrzyżowanego, to znaczy <zobaczyć Ojca>, to znaczy uwierzyć, że w świecie jest obecna miłość i że ta miłość jest potężniejsza od zła jakiegokolwiek, w które uwikłany jest człowiek, ludzkość, świat. Uwierzyć zaś w taką miłość, to znaczy uwierzyć w miłosierdzie. Miłosierdzie jest bowiem nieodzownym wymiarem miłości, jest jakby drugim jej imieniem a zarazem właściwym sposobem jej objawiania się i realizacji wobec rzeczywistości zła, które jest w świecie, które dotyka i osacza człowieka, które wdziera się do jego serca i może go <zatracić w piekle>." ${ }^{43}$ Stąd Krzyż Chrystusa stanowi tajemnicę najgłębszego pochylenia się Boga nad człowiekiem i nad tym, co człowiek - zwłaszcza w chwilach trudnych i bolesnych - nazywa swoim losem.

W szóstej części poematu zatytułowanej „Samarytanka” przemówi do Jezusa już sama kobieta. Jej uwaga skoncentruje się na symbolu studni, przy której spotkała Zbawiciela:

Owa studnia złączyła mnie z Tobą, owa studnia wprowadziła mnie w Ciebie.

Nie było wśród nas nikogo, tylko jej blask głęboki

drżący jak czysta źrenica w orbitach kamieni. ${ }^{44}$

Dowartościowanie przez Karola Wojtyłę w tym momencie obecności studni w Sychem, wydaje się być niezwykle istotne. Jego autorski zamysł jakby pieczętuje odkrycie Samarytanki i uzasadnia, że ta ściśle łącząca pokolenia Żydów i Samarytan studnia otworzyła przed nią drogę do nieznanego jej dotychczas bytowania. Z powyższego fragmentu może wynikać, że to nowe bytowanie Samarytanki polega głównie na przyjęciu przez nią prawdy, że w świetle zbawczej tajemnicy Chrystusa Bogu obce są etniczne podziały, a ona przynależy do jednej wielkiej rodziny ludzkości objętej bliskością nadejścia godziny mesjańskiej. ${ }^{45}$ Przywołana w tym kontekście jeszcze raz symbolika źrenicy wyraźnie nawiąże do doświadczenia, jakie jest udziałem córki, która tożsamościowo przynależy do domu swego ojca. Wcześniej, Samarytanka jakby nie miała do tego dostępu. Potrzebne było zatem doświadczenie, które już na zawsze przywróci jej ten jakże istotny brak. Według koncepcji Karola Wojtyły mogło to dokonać się dopiero w tajemnicy i poprzez tajemnicę synostwa Syna Bożego. Kobiecie zostanie wówczas przywrócone nie tylko owo pierwotne odczucie, że jest czyjąś córką, ale także i przede wszystkim

${ }^{43}$ Jan Paweł II, Dives in Misericordia, Lublin 1983, s. 25

${ }^{44}$ K. Wojtyła, Pieśń o blasku wody, w: Karol Wojtyła. Poezje. Dramaty. Szkice. Tryptyk rzymski. Jan Pawet II, dz. cyt., s. 99.

${ }^{45} \mathrm{~W}$ tym kontekście można uznać za kluczowy fakt podania przez św. Jana godziny przyjścia Samarytanki do studni Jakubowej i spotkania tam Jezusa: „Było to około godziny szóstej” (J 4, 6). Około godziny szóstej również, o czym przeczytamy w dalszej części czwartej ewangelii, rozegra się u Piłata sąd nad Jezusem i po ubiczowaniu oraz wyszydzeniu Zbawiciel usłyszy od Żydów: „Precz! Precz! Ukrzyżuj Go!” (por. J 19, 14-16). 
otworzy się przed nią nowa ontologiczna przestrzeń doświadczenia siebie jako córki Boga. Kolejne wersy ukażą - co jest bardzo ciekawe - że Jezus również uzna studnię Jakuba za miejsce decydujące w trakcie całego spotkania w Sychem. Fragment ten jest wyraźnie oddzielony od wypowiedzi kobiety i można go uznać - z racji zastosowania przez Karola Wojtyłę małych liter - za odpowiedź Jezusa, tak: ona mnie $w$ oczy twoje przeniosta $i$ w nich zamknęta. ${ }^{46}$ Przy tej okazji rodzi się pytanie: Jaką symbolikę mogłaby posiadać dla samego Zbawiciela studnia Jakubowa? Ponieważ sens posłannictwa Chrystusa zasadza się na głębi życia wewnętrznego Boga w Trójcy Świętej, to z perspektywy Syna Bożego studnia może przypominać o nieustannym zachowywaniu przez Niego Źródła Swojej Synowskiej Tożsamości. Bo specyfiką tajemnicy Boga Ojca jest właśnie bycie Źródłem i wszystko, co pochodzi z Tego Źródła jest przejawem Jego nieskończonej miłości. ${ }^{47}$ Nie ma bardziej wymownych słów niż:

Tak bowiem Bóg umiłował świat, że Syna swego Jednorodzonego dał, aby każdy, kto w niego wierzy, nie zginął, ale miał życie wieczne (J 3, 16).

Wydaje się zatem, że studnia Jakubowa miała także i o tym przedziwnie zaświadczyć, poprzez ukazanie nowego typu Boskiej asystencji w życiu każdego człowieka. Polega ona mianowicie: na objawieniu ojcostwa Boga poprzez Jego zaangażowanie w cierpienie ludzkości, które osiągnie swój pełen wymiar w ofierze odkupieńczej Syna.

Kierunek poetyckiej medytacji podjętej przez Karola Wojtyłę prowadzi nas obecnie do siódmej części utworu noszącej tytuł „Rozważań ponownych”. Refleksja, jakiej dokonuje tutaj Samarytanka jest próbą zebrania i nazwania kluczowych doświadczeń, które stały się jej udziałem. Dla naszej bohaterki spotkanie z Jezusem jest rzeczywistym przebudzeniem z duchowego letargu. Kobieta zwraca uwagę na pojawienie się w tym głębokim doświadczeniu nowej świadomości siebie. Dzięki temu dostrzeże, że duchowe dźwignięcie, jakiego dokonał w niej Zbawiciel było uzdrawiającym uwolnieniem z sideł tych struktur, które trzymały ją w niewoli samej siebie. ${ }^{48}$ Co więcej - ona zrozumie, że życie, jakie do tej pory wiodła było jakby nieustannym pozostawaniem poza rzeczywistym obrębem miłości i sensu:

${ }^{46}$ K. Wojtyła, Pieśń o blasku wody, w: Karol Wojtyła. Poezje. Dramaty. Szkice. Tryptyk rzymski. Jan Pawet II, dz. cyt., s. 99.

${ }^{47}$ G. Bagnard, Bóg Ojciec w objawieniu chrześcijańskim, w: Tajemnica Trójcy Świętej, dz. zb. pod red. L. Baltera, Poznań 2000, s. 10-11.

${ }^{48} \mathrm{~W}$ niezwykle interesującym opracowaniu nt. drogi nadprzyrodzonego pokoju i płodności eklezjalnej anonimowy autor dopowiada: „Chrystus mówi, że królestwo Boże jest w nas, ale nabiera ono mocy dopiero wtedy, kiedy jesteśmy wolni od samych siebie i z prostotą przyjmujemy miłość Bożą i życie Boże, które są jedną i tą samą rzeczywistością. Trzeba więc, aby Bóg wyciągnął nas z habitusu tego świata, a potem z nas samych, abyśmy pozywając się kolejnych warstw bezużytecznego balastu, odkryli przestrzeń Bożą i nasze ,ja” wieczne.” - Karmelita Bosy, Hezychia. Droga nadprzyrodzonego pokoju i płodności eklezjalnej, Kraków 2011, s. 122. 
Wtedy to ja - to ja, przytomna mojemu ocknieniu jak człowiek w przejrzystym nurcie przytomny własnemu odbiciu

- nagle dźwignięty z zwierciadła i przeniesiony w siebie...

Jak zostałam dźwignięta - nie wiem [...]

- i potem - sobie...

rozgraniczona - czyżby tylko przebudzeniem?

i prostym otwarciem ściany, przez którą chodziłam dotąd, nie wiedząc, że mnie dzieli ode mnie samej

- i nie tylko ode mnie.

O, jakże zostałam dźwignięta. Choć wszystko jest jak dawniej... ${ }^{49}$

Nakreślony obraz jest swoistym wprowadzeniem w rzeczywistość duchowego rozgraniczenia, jakiego doświadczyła Samarytanka w czasie epifanii przy studni Jakuba. Klucz interpretacyjny do tej problematyki może stanowić fragment Listu do Hebrajczyków, w którym rozgraniczające działanie Słowa Bożego w duszy ludzkiej jest porównane do ostrych cięć wywołanych mieczem obosiecznym:

Żywe bowiem jest Słowo Boże, skuteczne i ostrzejsze niż wszelki miecz obosieczny, przenikające aż do rozdzielenia duszy i ducha, stawów i szpiku, zdolne osądzić pragnienia i myśli serca (Hbr 4, 13).

Wydaje się zatem, że dzieło jakiego dokonuje Słowo Boże w człowieku polega głównie na wydobyciu i rozmontowaniu w głębi ludzkiego wnętrza tego, co nazywamy mechanizmem grzechu. Wyraźne nawiązanie do tej prawdy znajdujemy w antropologicznym studium Karola Wojtyły pt. „Osoba i czyn”. Autor stwierdza w nim m. in.:

Chodzi o to - ażeby dotknąć rzeczywistości ludzkiej w punkcie najbardziej właściwym

- w punkcie, na który wskazuje doświadczenie człowieka i z którego człowiek nie może się wycofać bez poczucia, że siebie zagubił. ${ }^{50}$

Tak więc, dalszą drogę interpretacyjną wyznacza już sam Karol Wojtyła ukazując prezentowaną przez siebie koncepcję antropologiczno-personalistyczną. Jej podstawowa teza opiera się na prawdzie, że najgłębsze korzenie dynamizmu człowieka tkwią w ludzkim wnętrzu i ono jest osnową bytu ludzkiego. W rozumieniu Karola Wojtyły ludzkie wnętrze jest to przestrzeń będąca siedzibą dwojakiego rodzaju sił i uzdolnień. $Z$ jednej strony człowiek doświadcza w sobie tego, co ludzkie, naturalne i co podlega grzechowi, z drugiej zaś może doświadczać tego, co ma charakter transcendentny i co wykracza poza ludzkie możliwości poznawcze.$^{51}$ Różnica pomiędzy tymi dwiema postaciami dynamizmu, a zarazem potencjalności człowieka, wyraża się głównie przez to, że pierwsza z nich ma

${ }^{49}$ K. Wojtyła, Pieśń o blasku wody, w: Karol Wojtyła. Poezje. Dramaty. Szkice. Tryptyk rzymski. Jan Pawet II, dz. cyt., s. 99.

${ }^{50}$ Tenże, Osoba i czyn, Lublin 2011, s. 70.

${ }^{51}$ Por. J. Galarowicz, Karol Wojtyła. Myśl o człowieka, Kraków 2014, s. 62-63. 
charakter uświadomiony, a druga nie. Stąd owe rozgraniczenie duchowe będące cechą nowego sposobu obecności Samarytanki może polegać na odkryciu przez nią prawdy o istnieniu własnej dychotomii wewnętrznej.

Część ósma poematu nosząca tytuł „Pieśń o blasku wody” wprowadza nas niewątpliwie w praktykowaną w Biblii ideę wznoszenia pieśni dziękczynnej na cześć Boga po doświadczeniu Jego cudownej interwencji. Najbardziej znanymi tego typu modlitewnymi utworami są: kantyk Mojżesza (Wj 15, 1-19), kantyk Balaama (Lb 22, 7-10), kantyk Tobiasza (Tb 13, 1-18), kantyk Judyty (Jdt 16, 1-17), kantyk trzech młodzieńców w piecu ognistym (Dn 3, 51-90), Benedictus czyli kantyk Zachariasza (Łk 1, 67-79), Magnificat czyli kantyk Maryi Matki Jezusa (Łk 1, 46-55) czy kantyk Symeona (Łk 2, 29-32). Te zbliżone do psalmu pieśni, które cechuje głównie podniosły i uroczysty charakter są tekstami chyba najbardziej wyrażającymi prawdę o wewnętrznym nastawieniu człowieka biblijnego. $Z$ tej perspektywy życie ludzkie rozpatruje się w powiązaniu z osobą działającego i uobecniającego się Boga, którego człowiek jest obrazem, dzięki czemu zdolny jest on do podjęcia dialogu ze swoim Stwórcą i do kształtowania swego życia na Boże podobieństwo. Poetycka pieśń uwielbienia Samarytanki, wpisuje się więc w tę jakże żywotną tradycję. Już na początku swego uwielbienia kobieta stara się wyliczyć te dobra, które stały się jej udziałem przy studni Jakuba i stwierdza z wdzięcznością, że jej źrenice pełne są już blasku i świadczą o przyjętym przez nią duchowym poznaniu:

\footnotetext{
A w samej głębi, z której przyszłam zaczerpnąć

Tylko wody dzbanem - tak już dawno do źrenic

przywiera ten blask... tyle, tyle poznania

znalazłam - ileż więcej niż dotąd!

Znalazłam w odbiciu tej studni tyle pustej w sobie przestrzeni.

O jak dobrze! $!^{52}$
}

Kantyk Samarytanki autorstwa Karola Wojtyły to pieśń niezwykle oryginalna, ponieważ nie istnieje jej odpowiednik biblijny. $Z$ treści tej pieśni wynika jasno, że dla naszej bohaterki droga do prawdziwej wolności otworzyła się dopiero wtedy, gdy spotkała Jezusa. Jak słusznie zauważa Krzysztof Dybciak, Samarytanka nim zaintonuje pieśń o wodzie żywota i spełnieniu swoich pragnień, wyzna ,jak” została wydźwignięta. ${ }^{53} \mathrm{~W}$ odczuciu kobiety będzie to jakby proste otwarcie ściany, przez która chodziła dotąd nie wiedzac, że dzieli ja od niej samej - i nie tylko od niej. ${ }^{54}$ A zatem, czy można się dziwić, że jej kantyk ostatecznie przerodzi się w pełną żaru błagalną modlitwę pozostania już na zawsze w przestrzeni oczu Jezusa?

${ }^{52}$ K. Wojtyła, Pieśń o blasku wody, w: Karol Wojtyła. Poezje. Dramaty. Szkice. Tryptyk rzymski. Jan Pawet II, dz. cyt., s. 100.

${ }^{53}$ Por. Por. K. Dybciak, Karol Wojtyła a literatura, dz. cyt., s. 43.

${ }^{54}$ Por. K. Wojtyła, Pieśń o blasku wody, w: Karol Wojtyła. Poezje. Dramaty. Szkice. Tryptyk rzymski. Jan Pawet II, dz. cyt., s. 99. 
Przypomina się tutaj postać oblubienicy z księgi „Pieśni nad pieśniami”, która po długich poszukiwaniach swego oblubieńca powie:

W upragnionym jego cieniu usiadłam,

a owoc jego słodki memu podniebieniu.

Wprowadził mnie do domu wina,

i sztandarem jego nade mną jest miłość. (Pnp 2, 3-4)

Końcowe akordy pieśni Samarytanki stanowią wyraźne potwierdzenie o dokonującym się w jej wnętrzu głębokim otwarciu na miłość Boga i Jego afirmującą obecność:

Nie zdołam Cię całego przenieść w siebie -

ale pragnę, byś pozostał jak w zwierciadle studni [...]

spojrzeniem zdumionych oczu

- oczu bardziej prześwietlonych niż smutnych. ${ }^{55}$

Poetycki kantyk zaintonowany przy studni Jakuba, łączy się więc nie tylko $\mathrm{z}$ pewną kulturą odsłaniania wpisanych w literaturę postaw religijnych, ale może stanowić wybitną dokumentację autorskiego dążenia do rekonstrukcji obecnej w tym utworze koncepcji człowieka. Jest to koncepcja, w której na pierwszy plan - jakby to powiedział Stefan Sawicki -wysuwa się tzw. moment religijny, moment przekraczający naturalność relacji do sacrum. ${ }^{56} \mathrm{~W}$ świetle tej formuły badawczej autorska wizja Karola Wojtyły, w której centrum znalazło się spotkanie Jezusa z Samarytanką, zdaje się w istotny sposób poszerzać biblijną narrację o tajemnicy świętości ludzkiego życia oraz znacząco przyczyniać się do właściwego odczytania głębi tożsamości człowieka, rozumianej zwłaszcza w perspektywie par excellence religijnej.

$\mathrm{Z}$ przeprowadzonych analiz mogą nasuwać się dwa zasadnicze wnioski. Po pierwsze, poemat Karola Wojtyły pt. „Pieśń o blasku wody” jest autorską medytacją, która prezentuje całkowitą spójność z logiką przesłania biblijnego. Zdaje się o tym świadczyć nie tylko dosłownie przywołany na początku utworu fragment z ewangelii św. Jana, który został poddany wnikliwej poetyckiej refleksji, ale także podjęty przez autora oryginalny sposób literackiego przetworzenia problematyki kategorii biblijnych, stanowiących rzeczywistą osnowę całego utworu. W przyjętej przez Karola Wojtyłę optyce interpretacyjnej mowa jest zasadniczo o dwóch biblijnych kategoriach: pragnieniu i widzeniu. Przeprowadzona analiza problematyki tych kategorii została ukazana w konfrontacji z dokonującym się na płaszczyźnie ducha procesem dojrzewania człowieka do podjęcia życiodajnego dialogu z Bogiem, czego przejawem może być chociażby zaintonowana przez główną bohaterkę utworu pieśń uwielbienia, stanowiąca jedno z najbardziej twórczych dopowiedzeń Karola

${ }^{55}$ Tamże.

${ }^{56}$ Por. S. Sawicki, Religia a literatura. Zarys problematyki badań, w: Inspiracje religijne $w$ literaturze, zb. zb. pod red. A. Merdas, Warszawa 1983, s. 18. 
Wojtyły do przekazu ewangelicznego. Jego autorskie pochylenie się nad problemem postrzegania przez człowieka własnej tożsamości może stanowić bardzo cenną egzemplifikację obecnych $\mathrm{w}$ tym utworze głównych założeń prezentowanej przez siebie antropologi. W jej świetle człowiek jawi się jako dzieło pochodzące z rąk Boga powołane do życia w miłości na Boży obraz i Boże podobieństwo (por. Rdz 1, 27). $Z$ tej fundamentalnej prawdy wynika zaznaczona wyraźnie w poemacie kwestia wszczepionych przez Stwórcę w ludzkim wnętrzu możliwości uzdalniających każdego człowieka do podjęcia drogi uczestnictwa w tajemnicach Bożej Mądrości (por. Mdr 6, 1-25) i osiągnięcia życia w całej swojej pełni. W tym kontekście niezwykle interesujący wydaje się być poetycki opis Karola Wojtyły przemiany dokonującej się we wnętrzu głównej bohaterki. Oto pod wpływem okazanej przez Syna Bożego zbawczej afirmacji, kobieta z Samarii zyskuje swoją nową tożsamość i odkrywa nowy typ Boskiej asystencji w ludzkim życiu, polegający na całkowitym zaangażowaniu Boga w cierpienia ludzkości. Dzięki temu może ona z ufnością otworzyć się na przyjęcie darowanej jej przez Chrystusa łaski wydźwignięcia ze stanu znalezienia się poza rzeczywistym obrębem miłości i doświadczyć duchowego uwolnienia ze skutków głębokiego zranienia swojej duszy. Wysoce oryginalne w ukazanej wizji może być również to, że dar swojej nowej samoświadomości Samarytanka otrzyma przy studni w Sychem, która z perspektywy samego Zbawiciela może przypominać o nieustannym zachowywaniu przez Niego Źródła Swojej Synowskiej Tożsamości. W ten sposób prezentowana dotąd antropologia, już tak ściśle powiązana z teologią, staje się jakby nieodłączna od chrystologii, a utwór Karola Wojtyły jeszcze bardziej zaznacza swój chrystocentryczny i chrystoformiczny charakter.

\section{BIBLIOGRAFIA:}

Ambroży Św., Wykład Ewangelii św. Lukasza, Warszawa 1977.

Bagnard G., Bóg Ojciec w objawieniu chrześcijańskim, w: Tajemnica Trójcy Świętej, dz. zb. pod red. L. Baltera, Poznań 2000, s. 9-15.

Balawajder K, Konflikty interpersonalne: analiza psychologiczna, Katowice 1992.

Ballestrero A., Wstuchani w Boga, w: Droga do nowego życia, dz. zb. pod red. S. Ruszczyckiego, Kraków 1982, s. 21-280.

Bogacz R., Ligas K., Biblijny aspekt spotkania Chrystusa z człowiekiem w twórczości Karola Wojtyty, w: Inspiracje biblijne, dz. zb. po red. T. Jelonki, Kraków 2007, s. 9-50.

Budzyń K., Kubacka-Jarecka D., Kryzys. Interwencja i pomoc psychologiczna, Toruń 2003;

Campenhausen H., Ojcowie Kościoła, Warszawa 1967, s. 9-50.

Dybciak K., Karol Wojtyła a literatura, Tarnów 1991.

Eugeniusz M. od Dzieciątka Jezus, Chcę widzieć Boga, Kraków 1998.

Forstner D., Świat symboliki chrześcijańskiej, Warszawa 1990.

Galarowicz J., Karol Wojtyła. Myśl o człowieku, Kraków 2014.

Jan Paweł II, Dives in Misericordia, Lublin 1983.

Jan Paweł II, Fides et ratio, Poznań 1998.

Jan Paweł II, Redemptor hominis, Wrocław 1994. 
Karmelita Bosy, Hezychia. Droga nadprzyrodzonego pokoju i płodności eklezjalnej, Kraków 2011. Katechizm Kościoła Katolickiego, Poznań 1994.

Léon-Dufour X., Stownik Nowego Testamentu, Poznań 1986.

Léon-Dufour X., Stownik teologii biblijnej, Poznań 1990.

Machniak J., Bóg i czlowiek w poezjach i dramatach Karola Wojtyły-Jana Pawła II, Kraków 2007. Michalski M., Antologia literatury patrystycznej, Warszawa 1975.

Moysa S., Teraz zaś trwaja te trzy, Warszawa 1986.

Pilecka B., Kryzys psychologiczny. Wybrane zagadnienia, Kraków 2004.

Sawicki S., Religia a literatura. Zarys problematyki badań, w: Inspiracje religijne $w$ literaturze, zb. zb. pod red. A. Merdas, Warszawa 1983, s. 9-20.

Terruwe A. A, Baars C. W., Integracja emocjonalna - jak uwierzyć, że jesteś kochany i potrafisz kochać, Poznań 2004.

Wojtyła K., Miłość i odpowiedzialność, Lublin 1982.

Wojtyła K., Pieśń o blasku wody, w: Karol Wojtyła. Poezje. Dramaty. Szkice. Tryptyk rzymski. Jan Pawet II, M. Skwarnicki, Kraków 2004, s. 95-100.

Zawada M., Podstawy architektury duchowej. Pokora, Kraków 2006.

Zawada M., Zaślubiny z samotnościa, Kraków 1999.

Zufii S., Nowy Testament. Postacie i epizody, Warszawa 2007.

\section{Streszczenie}

Powstały w 1950 roku utwór Karola Wojtyły pt. „Pieśń o blasku wody” jest poetycką medytacją prezentującą całkowitą spójność z logiką przesłania biblijnego. Zdaje się o tym świadczyć nie tylko dosłownie przywołany na początku utworu fragment $\mathrm{z}$ ewangelii św. Jana, który został poddany wnikliwej poetyckiej refleksji, ale także podjęty przez autora oryginalny sposób literackiego przetworzenia problematyki kategorii biblijnych, stanowiących rzeczywistą osnowę całego utworu. W przyjętej przez Karola Wojtyłę optyce interpretacyjnej mowa jest zasadniczo o dwóch biblijnych kategoriach: pragnieniu i widzeniu. Przeprowadzona analiza problematyki tych kategorii została ukazana w konfrontacji z dokonującym się na płaszczyźnie ducha procesem dojrzewania człowieka do podjęcia życiodajnego dialogu z Bogiem, czego przejawem może być chociażby zaintonowana przez główną bohaterkę utworu pieśń uwielbienia, stanowiąca jedno z najbardziej twórczych dopowiedzeń Karola Wojtyły do przekazu ewangelicznego. Jego autorskie pochylenie się nad problemem postrzegania przez człowieka własnej tożsamości może stanowić wybitną dokumentację dążenia do rekonstrukcji obecnej w tym utworze koncepcji człowieka. W jej świetle człowiek jawi się jako dzieło pochodzące z rąk Boga, powołane do życia w miłości na Boży obraz i Boże podobieństwo (por. Rdz 1, 27). Z tej fundamentalnej prawdy wynika zaznaczona wyraźnie w poemacie kwestia wszczepionych przez Stwórcę w ludzkim wnętrzu możliwości uzdalniających każdego człowieka do podjęcia drogi uczestnictwa w tajemnicach Bożej Mądrości (por. Mdr 6, 1-25) i osiągnięcia życia w całej swojej pełni. W tym kontekście niezwykle interesujący wydaje się być poetycki opis Karola Wojtyły przemiany dokonującej się we wnętrzu głównej bohaterki. Oto pod wpływem okazanej przez Syna Bożego zbawczej afirmacji, kobieta z Samarii zyskuje swoją nową tożsamość i odkrywa nowy typ Boskiej asystencji w ludzkim życiu, polegający na całkowitym zaangażowaniu Boga w cierpienia ludzkości. Dzięki temu może ona z ufnością otworzyć się na przyjęcie darowanej jej przez Chrystusa łaski wydźwignięcia ze stanu znalezienia się poza rzeczywistym obrębem miłości i doświadczyć duchowego uwolnienia ze skutków głębokiego zranienia swojej duszy. Wysoce oryginalne w ukazanej wizji może być to, że dar swojej nowej samoświadomości Samarytanka otrzyma przy studni w Sychem, która z perspektywy samego Zbawiciela może przypominać o nieustannym zachowywaniu przez Niego Źródła Swojej Synowskiej Tożsamości. W ten sposób prezentowana dotąd antropologia, już 
tak ściśle powiązana z teologią, staje się jakby nieodłączna od chrystologii, a utwór Karola Wojtyły jeszcze bardziej zaznacza swój chrystocentryczny i chrystoformiczny charakter.

Słowa kluczowe: Wojtyła, kategorie biblijne, Samarytanka, pieśń duszy, filozofia poezji, antropologia literatury, Biblia, poemat religijny, poetycka medytacja.

\section{ON BIBLICAL CATEGORIES IN KAROL WOJTYŁA’S POEM "THE SONG OF THE BRIGHTNESS OF WATER"}

\section{Sum mary}

“The Song of the Brightness of Water", a piece by Karol Wojtyła created in 1950, is a poetic meditation in complete agreement with the logic of the biblical message. This seems to be demonstrated not only by the directly quoted fragment from the Gospel according to John at the beginning of the poem, which was subjected to in-depth poetic reflection, but also by the original literary transposition of the subject-matter of the biblical categories, which create the ambience of the entire poem. The focus of the interpretation adopted by Karol Wojtyła is on two biblical categories: longing and perception. The analysis of these categories was contrasted with the spiritual process of an individual's becoming mature enough to enter into a life-giving dialogue with God, which can be observed, for instance, in the song of adoration sung by the protagonist of pain, constituting one of the most-creative extensions of the Gospel's message by Wojtyła. His focus on the individual's perception of his/her identity can serve as brilliant evidence of the attempt to reconstruct the concept of the human being present in the poem. In the light of this concept the human is a work of God, created to live in love, and in the likeness and image of God (cf. Gen 1, 27). This fundamental truth is the source of the issue clearly depicted in the poem of the possibility embedded by the Creator in each human being, enabling $\mathrm{him} /$ her to participate in the mysteries of God's Wisdom (cf. Wisdom 6, 1-25) and living life to its fullest. In this context Karol Wojtyła's poetic description of the main protagonist's transformation is extremely fascinating. Under the influence of the saving affirmation of the Son of God, the woman from Samaria gains a new identity and discovers a new type of God's assistance in human life, i.e. His complete involvement in human suffering. Thanks to this, she is able to fully accept the grace given by Christ to enable her to rise above the state of being separated from experiencing love and being released from the consequences of the deep wounding of her soul. The highly original aspect of this vision is that the Samaritan receives the gift of a new self-awareness at the well in Shechem, which from the perspective of the Saviour Himself can symbolise His incessant preservation of the Source of His Filial Identity. In this way the anthropology presented so far, strictly connected with theology, becomes inseparable from Christology, emphasising the Christocentric and Christoformic nature of this poem by Karol Wojtyła.

Key words: Wojtyla, the biblical categories, the Samaritan, the song of soul, the philosophy of poetry, the anthropology of literature, Bible, the religious poem, the poetic meditation. 